\title{
Physical Parameters of Tropical Wetlands in Lake Victoria Basin: A Case Study of Kigwal/Kimondi, Nyando and Nzoia Wetlands
}

Mule Shadrack $^{1 *}$, Nguta Charles ${ }^{2}$, Geoffrey Kamau ${ }^{3}$, Ongera Gilbert ${ }^{1}$, Wangila Phanice ${ }^{1}$, Kiplimo Joyce ${ }^{1}$ and Chirchir Dennis $^{1}$

${ }^{1}$ Department of Physical Sciences, University of Kabianga, P.O Box 2030, 20200, Kericho, Kenya

${ }^{2}$ Department of Physical Sciences, Laikipia University, P.O Box 1100, 20300, Nyahururu, Kenya

${ }^{3}$ Department of Chemistry, University of Nairobi, P.O Box 30197, G.P.O, Nairobi, Kenya

\begin{abstract}
This study entailed the assessment of physical parameters of selected tropical wetlands within Lake Victoria Basin. The research study measured rainfall, flow rate, turbidity, and $\mathrm{pH}$ of Kigwal/Kimondi, Nyando and Nzoia wetland ecosystems found within eastern side of Lake Victoria Basin by use of Vernier Calliper Instrument. The study found out that approximately 78 to $89 \%$ of recharge water was retained with the highest calculated water budget being for Nzoia wetland $\left(26.24(0.99) \times 10^{6} \mathrm{~m}^{3}\right)$ during rainy season with Kigwal/Kimondi $\left(8.85(2.91) \times 10^{6} \mathrm{~m}^{3}\right)$ and Nyando $(11.47$ $\left.(0.75) \times 10^{6} \mathrm{~m}^{3}\right)$. There was a seasonal variation of flow rate, $\mathrm{pH}$, and turbidity with rain season indicating high levels of turbidity, flow rate and variable $\mathrm{pH}$ levels in the wetland ecosystems as compared to dry seasons. A statistically significant correlation existed between the measured parameters with coefficient of correlation ranging from $r=0.8976$ to 0.9987 with $p<0.05$ ). Turbidity values of the three wetlands at the inlets during rainy season were above the recommended values by EPA but decreased considerably at the exit of the wetlands to within the recommended NTUs by EPA of 1 to 5 NTUs. There was a highly correlated relationship between rainfall amounts, flow rate and turbidity.pH values ranged from slightly acidic $(6.79( \pm 0.55))$ at the inlets) to basic nature $(8.44( \pm 0.17))$ especially at the outlets of the wetland ecosystems. Intervention programs should be initiated to ensure that physical properties of wetlands are secured.
\end{abstract}

Keywords: Wetland; Parameters; Tropical; Water quality

\section{Introduction}

Under environmental conditions, rainfall is an important factor affecting mobility of river water, sediments, pollutants and biodiversity of wetland ecosystems. The hydrologic and hydraulic characteristics of a wetland influence all wetland functions and, consequently, should be an initial focus of a wetland evaluation. The processes by which water is introduced, temporarily stored, and removed from a wetland are commonly known as the water budget. Water is introduced to a wetland through direct precipitation, overland flow (or runoff), channel and overbank flow, groundwater discharge, and tidal flow. All these processes increase as rainfall amounts increases [1,2].

Surface water processes within a wetland are tied to both local and regional precipitation patterns. Precipitation can influence a wetland water budget directly through rain within the physical boundaries of the wetland and the associated runoff, or indirectly through inflows from upstream watersheds. An increase in rainfall amounts tends to increase flow rate of rivers, increase in water runoff and soil erosion which therefore can increase the rate of transport of hydrocarbons from their nonpoint sources [3]. As long as agricultural activities are done, then there are a certain proportion of sediments, fertilizers and pesticides reaching natural systems via surface runoff during strong rainfall events. Surface waters, including surface runoff and drainage outflows increases with increase in rainfall amounts and river flow rate. Increase in precipitation correlates with increase in river flow rate. Peak water velocities through the wetland should not exceed 0.457 $\mathrm{m} / \mathrm{s}[4,5]$. High velocities can wash out rooted vegetation and scour deposited sediments. Ideally, flow velocities should be less than 0.183 $\mathrm{m} / \mathrm{s}$. A wetland with a high vegetation density will correspond to low flow rate and low turbidity values [5]. reported a $60-90 \%$ reduction factor for turbidity in a constructed wetland at low flow rates [6]. A wetland vegetative cover is reported to provides dominant drag forces which increases manning coefficient of such wetland by a factor of 10 20 [7-9].
In natural streams, the manning coefficient values vary greatly with most research showing that the coefficient values decreases with stage, at least up to bank-full. Overbank manning coefficient values for a given reach will vary greatly depending on the time of year and the velocity of flow. Summer vegetation will typically have a significantly higher manning coefficient value due to leaves and seasonal vegetation. Research has shown, however, that manning coefficient values are lower for individual shrubs with leaves than for the shrubs without leaves. This is due to the ability of the plant's leaves to streamline and flex as the flow passes them thus lowering the resistance to flow. High velocity flows will cause some vegetation (such as grasses and forbs) to lie flat, where a lower velocity of flow through the same vegetation will not [10].

Decreased flow rate increases retention time and water/macrophyte contact and removes suspended solids. Removal of water soluble as well as particle-bound compounds is accomplished by high vegetative cover which increases water/saprophyte contact and increases deposition of suspended sediments. Wetland water flow rate is thus a factor which affects wetland retention rate as they are inversely proportional [2].

Temperature plays a significant role in controlling the nature and the extent of microbial hydrocarbon metabolism, which is of special

*Corresponding author: Mule Shadrack, Department of Physical Sciences University of Kabianga, P.O Box 2030, 20200 Kericho, Kenya, Tel: 020-2380362 E-mail: muleshadrack@gmail.com,muleshadrack@glacinternational.co.ke

Received November 06, 2014; Accepted December 30, 2014; Published January 05, 2015

Citation: Shadrack M, Charles N, Kamau G, Gilbert O, Phanice W, et al(2015) Physical Parameters of Tropical Wetlands in Lake Victoria Basin: A Case Study of Kigwal/Kimondi, Nyando and Nzoia Wetlands. J Environ Anal Toxicol 5: 254. doi:10.4172/2161-0525.1000254

Copyright: @ 2015 Shadrack M et al. This is an open-access article distributed under the terms of the Creative Commons Attribution License, which permits unrestricted use, distribution, and reproduction in any medium, provided the original author and source are credited. 
significance for in situ bioremediation. Degradation and solubility of less soluble hydrophobic substances, such as aliphatic and polyaromatic hydrocarbons, are temperature dependent [2]. An increase in wetland temperature decreases viscosity of hydrocarbons therefore affecting their degree of distribution and diffusion rates. Therefore, higher reaction rates due to smaller boundary layers are expected at elevated temperatures. Increased volatilization and solubility of some hydrocarbons occur at elevated temperatures [11-14].

The loss of organic hydrocarbons through processes involving volatilization, photodecomposition, and, more important, microbial degradation is expected to be more rapid under tropical and subtropical wetland conditions $\left(15-22^{\circ} \mathrm{C}\right)$ than in less temperate environment [1518]. Higher temperature in tropical areas might favor both microbial and chemical decomposition. Gamma $\mathrm{HCH}$ has been shown to decompose faster at $35^{\circ} \mathrm{C}$ than at $25^{\circ} \mathrm{C}$ in a flooded soil [11]. High temperature decreases adsorption and favors desorption of hydrocarbons, which may result in higher amounts of hydrocarbon dissolved in sediment water and faster dispersion [12]. Diurnal variations in light intensity and temperature can lead to marked variations in photosynthetic activity in floodwater, resulting in water $\mathrm{pH}$ changes marked as two $\mathrm{pH}$ units within a day.

Temperature may also influence the adsorption of hydrocarbons by soil particles whose process is usually exothermic. Higher temperatures probably decrease adsorption of hydrocarbons by soil particles and the adsorbed hydrocarbons are released to water. Solubility of hydrocarbons into water is also temperature dependent, thus leading to a decrease in adsorption when temperature rises [19-22].

The $\mathrm{pH}$ level of water influences the degradation of some hydrocarbons. Some pesticides, particularly carbamate and organophosphate hydrocarbons, undergo a chemical breakdown known as alkaline hydrolysis in the presence of alkaline water. Depending on the specific chemical properties of the hydrocarbon, the $\mathrm{pH}$ of river water and length of time that the hydrocarbon is in contact with the water will affect the attenuation of hydrocarbons with the breakdown happening relatively rapidly. Water with a $\mathrm{pH}$ value between 8 and 9 can cause a rapid hydrolysis to the point that the degree of chemical activity is greatly diminished or lost $[23,24]$. Most wetland ecosystems have water $\mathrm{pH}$ ranging from 6.8 to 7.5 during rainy season and a pH of 7.8 to 9 during dry season [22]. The upper end of the $\mathrm{pH}$ limits is associated with $\mathrm{CO}_{2}$-free water in contact with carbonate rocks and can acquire a $\mathrm{pH}$ of 10 and in contact with some silicates, a $\mathrm{pH}$ of up to nearly 11 [4]. Since most surface waters emit $\mathrm{CO}_{2}$ to the atmosphere, such alkalinities are not attained. A reasonable upper limit of $\mathrm{pH}$ in most near-surface environments is near $9.0[25,26]$. Increased temperature or excess pollutants may result in higher algal and plant growth, which may cause $\mathrm{pH}$ levels to increase depending on the buffering capacity of water.

Turbidity is a measure of the degree to which water loses its transparency due to the presence of suspended particulates. The more total suspended solids in the water, the murkier it seems and the higher the turbidity [5]. Turbidity is considered as a good measure of the quality of water. There are various parameters influencing the cloudiness of the water. Some of these are: phytoplankton, sediments from erosion, re-suspended sediments from the bottom (frequently stir up by bottom feeders like carp), waste discharge, algae growth, urban runoff, matter from decaying vegetation, and industrial waste and sewage. Turbidity is usually measured in Nephelometric Turbidity Units (NTUs) or Formazin Nephelometric Units (FNU) depending on the wavelength of light used to make the measurement $[27,28]$.

During periods of low flow, many rivers have clear green color, and turbidities are low, usually less than 1NTU. During a rainstorm, matter from the surrounding land is washed into the river, changing the water to a muddy brown color and increasing the turbidity. During high flows, water velocities are faster and water volumes are higher, which can stir up and suspend material from the river bed causing higher turbidities [12]. Turbidity is an indicator of the concentration of suspended sediments in the water. Sediments are a natural part of streams and wetlands and even the most pristine streams in undeveloped watersheds will run muddy during high flows. The establishes that the turbidity of drinking water shouldn't be more than 5NTU, and should ideally be below 1 NTU [29-31]

\section{Methodology}

\section{Sites descriptions}

Three tropical wetland ecosystems were selected due to their geographical location with respect to their geographical locations within the Lake Victoria Basin (Figure 1). They included: Kigwal/ Kimondi wetland within the Kimondi River a tributary of River Yala; River Nzoia wetland at the mouth of River Nzoia and River Nyando wetland at the mouth of River Nyando.

Kimondi wetland (Figure 2) is positioned at $0^{\circ} 12^{\prime}-0^{\circ} 16^{\prime} \mathrm{N} / 35^{\circ} 10^{\prime}$ $35^{\circ} 16^{\prime} \mathrm{E}$, and measures approximately $12 \mathrm{Km}$ long and $6 \mathrm{Km}$ wide and covers approximately 4,800 ha (Figure 3). Kimondi wetland is situated in the catchment area of Kigwal River a tributary of River Yala within Kimondi and Kigwal administrative units of Nandi County. The wetland receives its waters from the North escarpment of Nandi Hills and from areas close to Moi University. The predominant vegetation of the wetland is Cyperus papyrus which forms a thick fringe within the wetland, Phragmites mauritianus is dominantly in shallower areas and swamp grasses are found around the wetland periphery. The swamp complex is by far the most natural wetland in comparison with the other two wetlands (River Nzoia and River Nyando wetlands) with minimum anthropogenic interference although farming activities around it are a future threat to its existence. The swamp is also a habitant of the rare and threatened sitatunga animals whose survival depends on the existence of the wetland ecosystem. The swamp acts as a natural filter for a variety of biocides and other agricultural pollutants from the surrounding catchment, and also removes silt from the river as it flows downstream to River Yala.

River Nzoia wetland (Figure 4) $\left(1^{\circ} 00-1^{\circ} 09^{\prime} \mathrm{N} / 34^{\circ} 57^{\prime}-35^{\circ} 05^{\prime} \mathrm{E}\right)$ is situated at the mouth of River Nzoia which originates from Cherangani Hills at a mean elevation of $2300 \mathrm{~m}$ above sea level (a.s.l) and drains into Lake Victoria at an altitude of 1000 m.a.s.l. River Nzoia runs South-West and measures about $334 \mathrm{~km}$ with a catchment area of about $12,900 \mathrm{~km}^{2}$, and a mean annual discharge of $1.777 \times 10^{9} \mathrm{~m}^{3} /$ year. This wetland is approximately $20 \mathrm{~km}$ long from NW-SE and $1-5 \mathrm{Km}$ wide and extends about 6,000 ha. The swamp is grassy with stands of papyrus reeds along the river banks. River Nzoia Basin lies between latitudes $1^{\circ} 30^{\prime} \mathrm{N}$ and $0^{\circ} 05^{\prime} \mathrm{S}$ and longitudes $34^{\circ}$ and $35^{\circ} 45^{\prime} \mathrm{E}$. The major land use within the basin area is agriculture with maize, wheat grown at the catchment area and sugarcane within the plains of River Nzoia. It is estimated that 4,000 ha of River Nzoia wetland has been converted to agriculture thus affecting the normal functioning of the wetland ecosystem.

River Nyando drains from Nandi highlands which is at an 
Citation: Shadrack M, Charles N, Kamau G, Gilbert O, Phanice W, et al (2015) Physical Parameters of Tropical Wetlands in Lake Victoria Basin: A Case Study of Kigwal/Kimondi, Nyando and Nzoia Wetlands. J Environ Anal Toxicol 5: 254. doi:10.4172/2161-0525.1000254

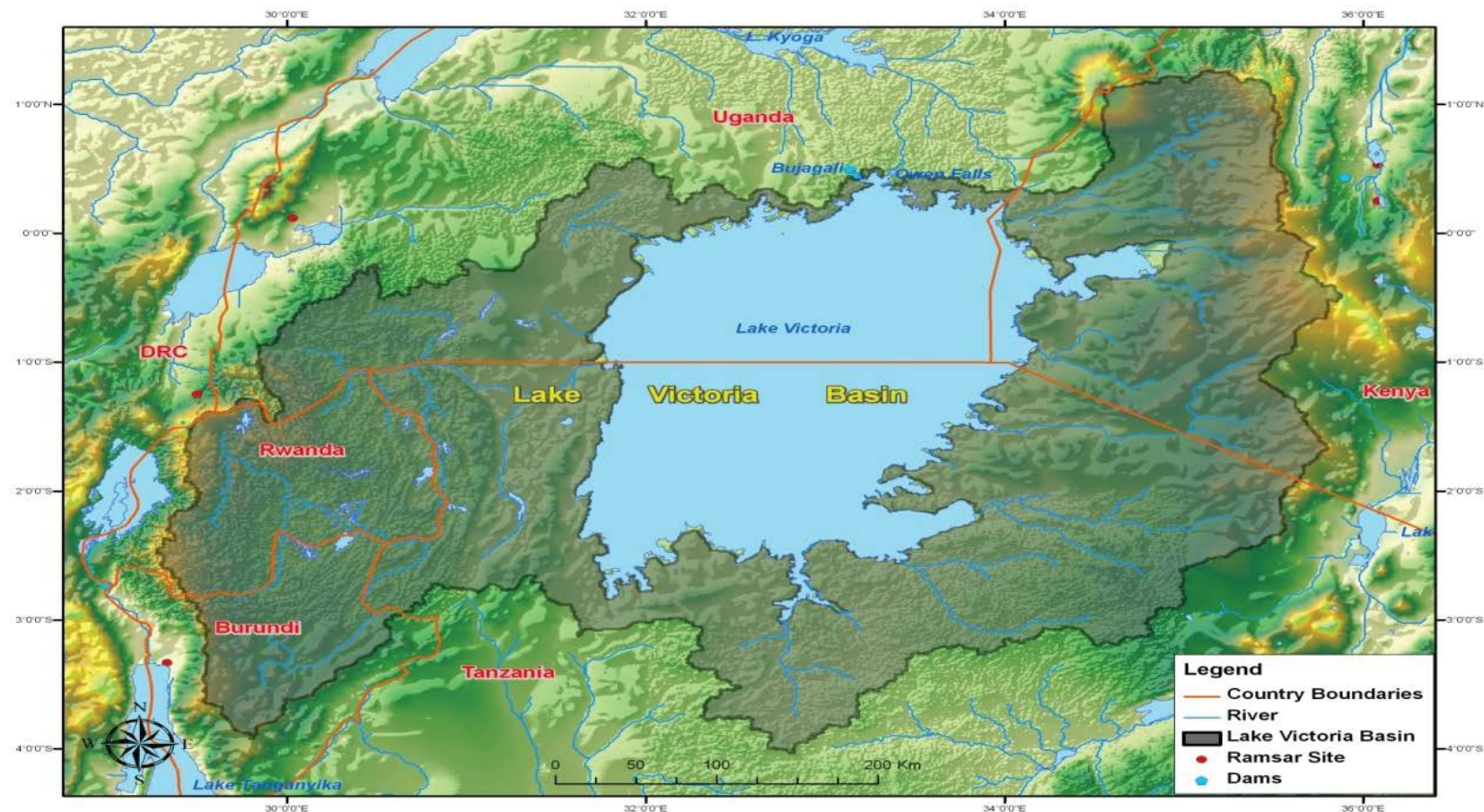

Figure 1: A map showing the drainage system of Lake Victoria Basin as adapted from Index of /gridnairobi.unep.org $3300 \times 2550$ Search by image Lake Victoria Basin. 13-Mar-2008 16:04 4.9M

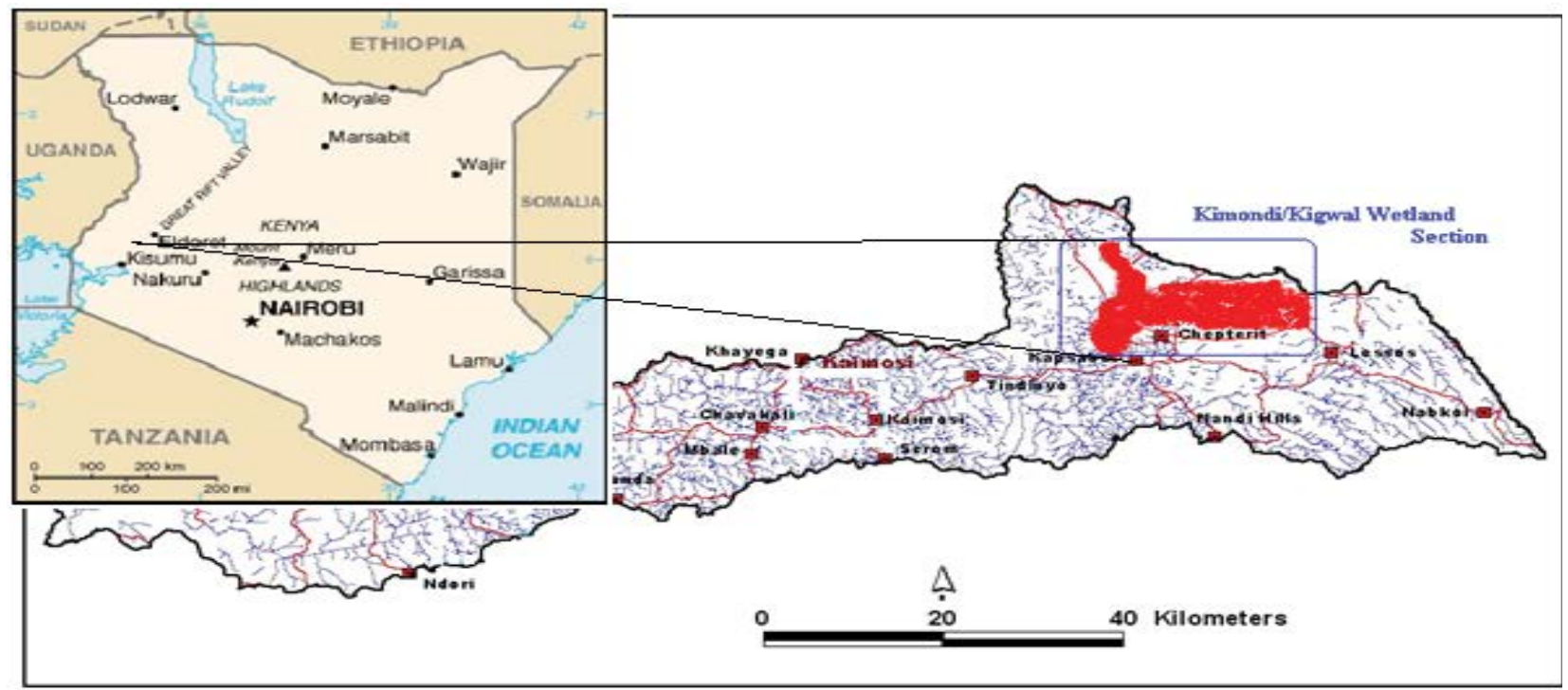

Figure 2: A map of River Yala Basins with specific interest of Kimondi wetland as adapted from Hunges and Hunges, 1992.

altitude of 1,700 m.a.s.l and terminates at Lake Victoria lakeshore where Nyando wetland is situated at an elevation of 1,135 m.a.s.l. River Nyando wetland is situated along the mouth of the river and it measures $15 \mathrm{~km}$ from W-E and some $6 \mathrm{~km}$ from N-S and covers about 5300 ha. Agricultural activities (tea farming, maize, sugarcane, keeping of livestock) and growing population have significantly contributed to the loss of the wetland [11].

\section{Methodology for parameter measurements}

Each selected wetland was divided into three sections or tanks (inlet tank, mid wetland tank and outlet tank) with specific measurements for each tank taken with respect to depth, width and length. The length measurements were critical in calculating recharge and discharge water volumes in each tank. Each tank was partitioned into two diagonal lines which were used to take ten physical parameter measurements within the specific tank. Seasonal measurements of the physical parameters were done during rainy season (August-September-October) and dry season during the months of November to March in the year 2012 and 2013. Surface water physical parameters (temperature, $\mathrm{pH}$, turbidity and water flow rate) were measured insitu using specific probes of 
LabQuest Vernier Caliper (Version 3) instrument at depths of 10 to $20 \mathrm{~cm}$ at the inlet, midpoint and outlet (Figure 5) of the selected wetland ecosystems. The measurements were validated using $\mathrm{HACH}$ SensIon instrument. Rainfall amount measurements were retrieved Meteorological Department (Meteorological Department, 2014) from the year 2009 to December, 2013. All measurements were recorded and descriptively analyzed for mean and standard deviation of the means using Microsoft Excel program.

\section{Results and Discussion}

\section{Rainfall variation in lake victoria basin}

The mean rainfall amount of Lake Victoria Basin for the years 2009 to 2013 as recorded by Kenya Meteorological Department (Meteorological Department, 2014) is shown in Figure 6 [13,17]. There was an increase in rainfall amounts from the months of March to May in each year. There was a drop in rainfall amounts during the months of November to February of each year which corresponds to a dry spell. The wetlands are also expected to have high water flow rates and, increase in turbidity values during rainy season as compared with dry season. The rainfall amounts are instrumental in regulating physical parameters of a wetland ecosystem [27].

\section{Wetland water budget}

Wetlands act as protective natural sponges by capturing, storing and slowly releasing water over a long period of time, thereby reducing the impact of floods [3]. The values of calculated water budget (using the equation below) for the respective wetlands is as shown in Table 1 recorded in Table 1 were calculated using the equation below:

Volume $\oint$ water $=U_{w} \times A_{\text {cwo }} \times l$

Where $U_{w}$ is the flow rate in $\mathrm{m} / \mathrm{s}$ and $A_{\text {cwo }}$ is the cross sectional area and $l$ is the length of the tank.

Nyando and Nzoia wetlands had high water retention budget as indicated in (Table 1) above and Kigwal/Kimondi recorded the least in the two seasons of study. This may be attributed to the wetlands drainage basins, wetland topography, and wetland land coverage. Kigwal/Kimondi wetland measures approximately $12 \mathrm{Km}$ long and 6 $\mathrm{Km}$ wide and covers approximately 4,800 ha and is situated at one of River Yala tributaries at the Nandi area whereas Nyando wetland which is situated at the mouth of River Nyando wetland measures $15 \mathrm{~km}$ from W-E and some $10 \mathrm{~km}$ from N-S and covers about 5300 ha. River Nzoia drains from Cherangani Hills has R.Nzoia wetland at its mouth and is approximately $20 \mathrm{~km}$ long from NW-SE and 1-5 Km wide and extends about 6,000 ha. The Nyando and Nzoia basins are so expanse that the rivers drain from large areas as compared to Kigwal/Kimondi wetland. The water budget is also affected by the vegetative cover which occupies greater volume of the wetland and allows more water to be discharged or to overflow from the wetland especially during rain seasons.

\section{Mean surface water temperature of selected wetland ecosystems}

Mean surface water temperatures recorded for the three selected wetland ecosystems are as shown in Figure 7 below with high mean surface water temperatures observed at the inlet of the wetland ecosystems in both seasons and lower overall temperatures at the mid wetlands which is attributed to greater vegetative cover as compared to the inlet and outlet. The recorded mean temperatures are in agreement with what reported for constructed wetland ecosystems in Netherlands [16] for natural wetland ecosystems. Kigwal/Kimondi wetland recorded lower surface water temperatures as compared to River Nyando and River Nzoia wetland ecosystems due to its geographical position within Lake Victoria Basin. It is located within the Nandi highland and the latter are in the low land of Lake Victoria Basin. There were generally lower surface mean water temperatures during rainy season as compared to dry season. Lower environmental temperatures, cold weather and immense growth of vegetation within the wetlands may have contributed to this observation. Temperature has an effect on residual pollutants especially those which are volatile by increasing their concentrations in the gas phase while reducing their concentrations at the surface of wetland water as indicated by the Henrys' constant of each pollutant. It is expected that the levels of pollutants which are temperature dependent will be lower in the inlets and outlets of the wetland tanks as the temperature increases.

\section{Seasonal variation of $\mathrm{pH}$ values}

Figure 8 below indicates the seasonal variation of $\mathrm{pH}$ values within the selected wetland ecosystems. There was an increase in mean $\mathrm{pH}$ values from inlet to outlet of the wetland ecosystems in both seasons with dry season recording higher $\mathrm{pH}$ values than the rain season in the respective wetland tank of the wetland ecosystem. Kigwal/Kimondi wetland mean $\mathrm{pH}$ values increased from slightly acidic nature to basic whereas the wetland ecosystems from slightly acidic nature to basic at the outlet. Nyando and Nzoia wetland ecosystems had the mean $\mathrm{pH}$ values between slightly basic to basic natures with Nyando wetland ecosystem recording up to $\mathrm{pH}$ of 9 at the outlet during dry season. Farming activities taking place in Nyando and Nzoia wetland ecosystems may have introduced pollutants which have affected the $\mathrm{pH}$ values unlike Kigwal/Kimondi wetland ecosystem. The increase in $\mathrm{pH}$ values for Kigwal/Kimondi wetland ecosystem at the mid wetland and outlet may be attributed to the degradation of vegetation at the midpoint. A positive statistically significant seasonal correlation $(\mathrm{r}=0.748, \mathrm{p}<0.05)$ of mean surface water $\mathrm{pH}$ for Kigwal/Kimondi wetland and River Nyando wetland ecosystem $(\mathrm{r}=0.934 ; \mathrm{p}=0.000)$ was noted. River Nzoia wetland recorded a weak positive, statistically insignificant seasonal correlation $(r=0.394 ; p>0.05)$ of mean surface $\mathrm{pH}$ values. This may be attributed to the increase in anthropogenic activities upstream which lead to this effect.

\section{Seasonal variation of flow rate values}

(Figure 9) shows the variation of water flow rate $(\mathrm{m} / \mathrm{s})$ of Kigwal/ Kimondi, River Nyando and River Nzoia wetland river water. There was a corresponding seasonal decrease in flow rate as river water traversed through the three wetlands with the outlet recording the lowest values. This may be attributed by the low topography as the wetland moved downstream, greater vegetative density and water spread within the wetlands which reduced the flow rates of river water in the selected wetland ecosystems. The high flow rates were due to high rainfall amounts, the area topography and less vegetative cover in the river systems. An increase in water flow contributed to high water turbulence, high turbidity and water spread within the wetlands. Anthropogenic activities along the river basins could affect water flow rate within the wetlands and thus affect their retention abilities. The recorded water flow rates in the three wetland ecosystems were in accordance with EPA (1993) of between 0.001 to $0.603 \mathrm{~m} / \mathrm{s}$ [22]. A strong positive statistically significant seasonal correlation between the recorded flow rate values for the three wetland ecosystems (Kigwal/ 
Citation: Shadrack M, Charles N, Kamau G, Gilbert O, Phanice W, et al (2015) Physical Parameters of Tropical Wetlands in Lake Victoria Basin: A Case Study of Kigwal/Kimondi, Nyando and Nzoia Wetlands. J Environ Anal Toxicol 5: 254. doi:10.4172/2161-0525.1000254

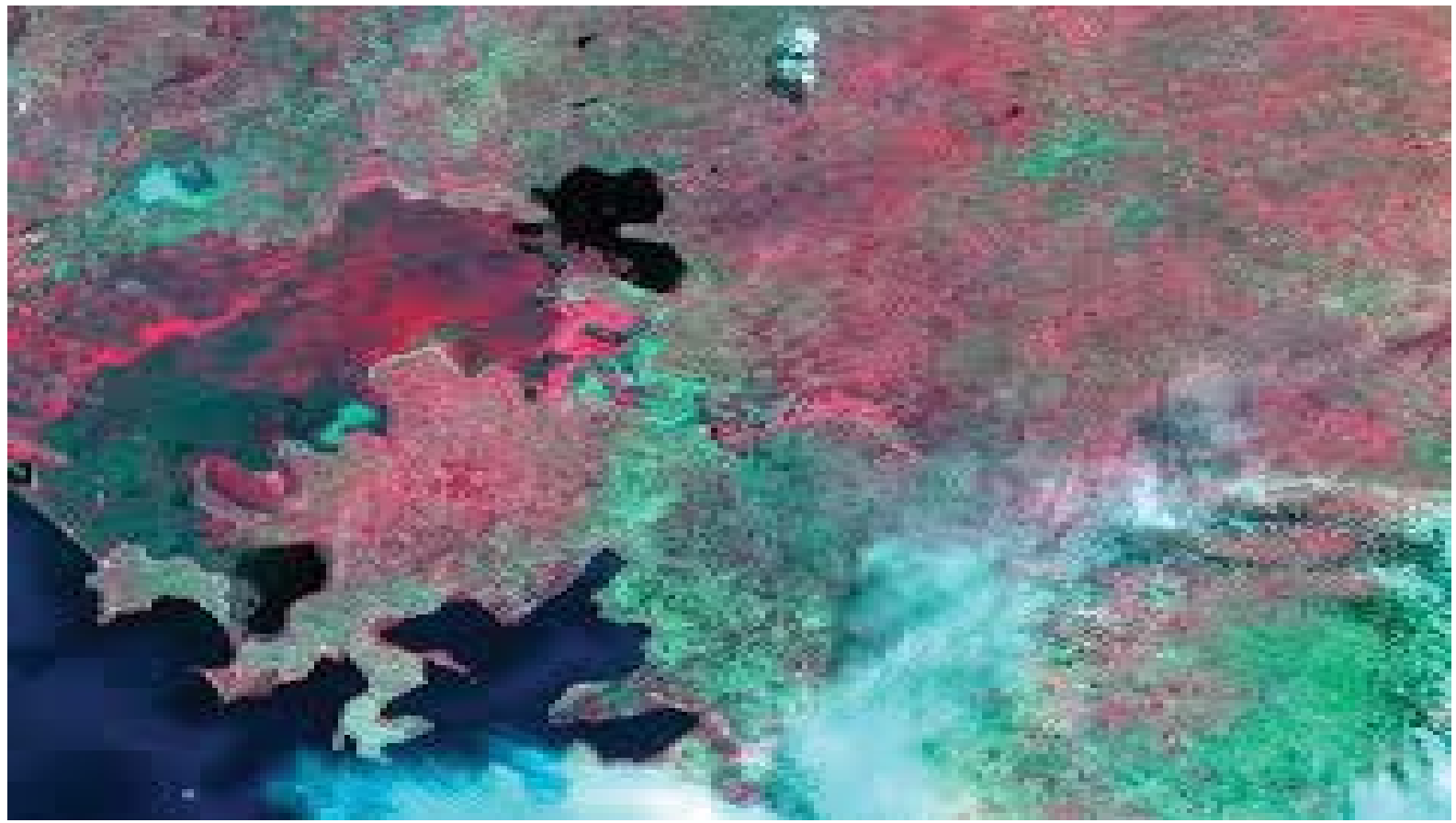

Figure 3: A multispectral imagery of Nzoia River basin from the NASA's EO-1 satellite on August 23, 2008/ NASA, EO-1.

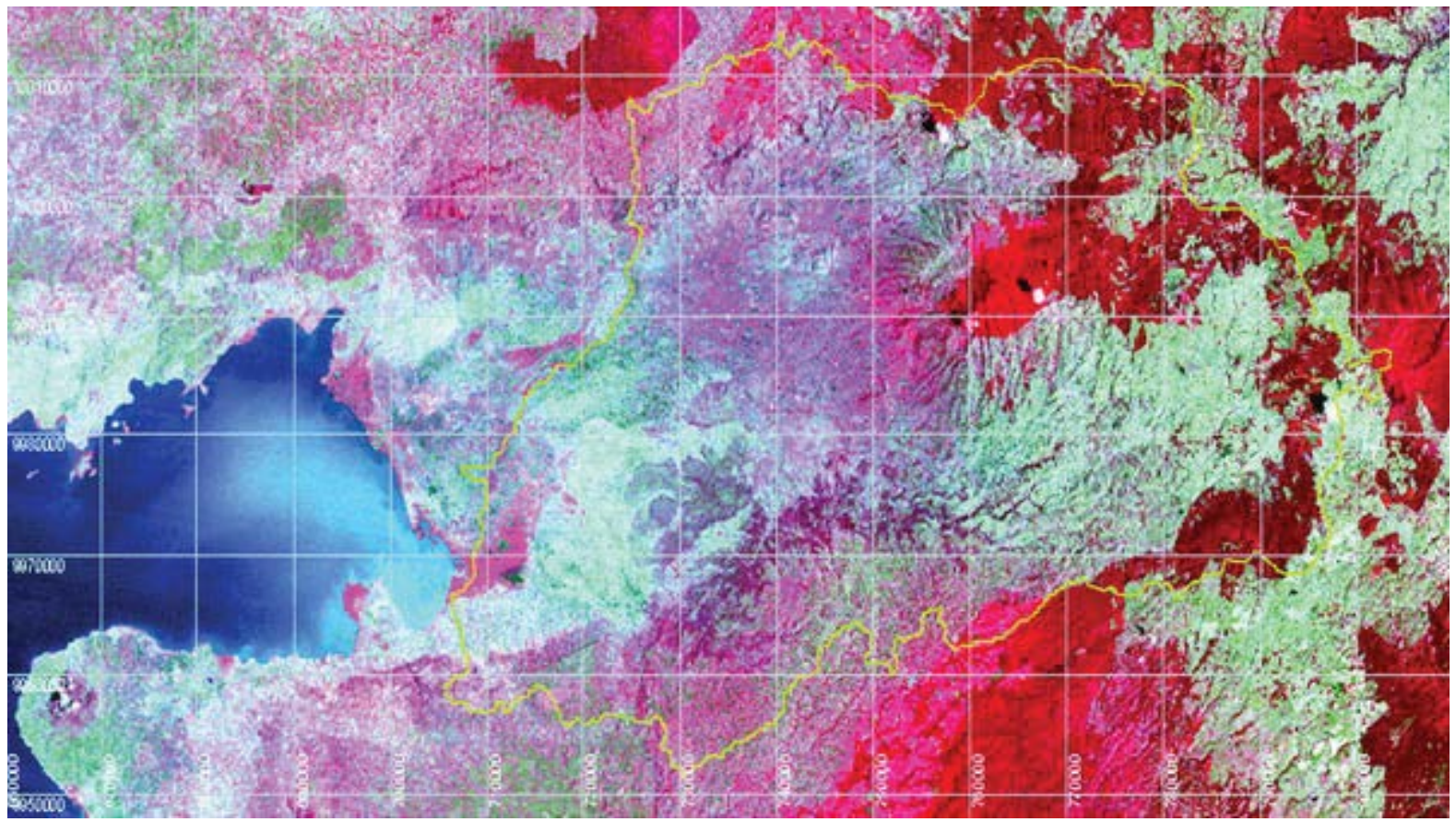

Figure 4: A Landsat Thematic Mapper image taken in 2000 of the Nyando River basin and surrounding area (basin boundary superimposed in yellow). The filmy white plume on the lake is sediment carried by River Nyando into Lake Victoria

Kimondi: $\mathrm{r}=0.981, \mathrm{p}=0.023$; River Nyando: $\mathrm{r}=0.958 ; \mathrm{p}=0.020$ and River Nzoia wetland: $r=0.934, p=0.000$ ).

\section{Seasonal variation of turbidity values}

Figure 10 shows the mean surface water turbidity values for both dry and rainy seasons for Kigwal/Kimondi, River Nyando and River
Nzoia wetland ecosystems. There is an observed decrease in turbidity values from inlet to outlet of each wetland ecosystem measured due to an increase in sedimentation as the respective river passed through the wetland thus the ability of the wetlands to retain sediments was observed during both seasons. There was a remarkable seasonal variation of turbidity values with rainy season recording the highest 


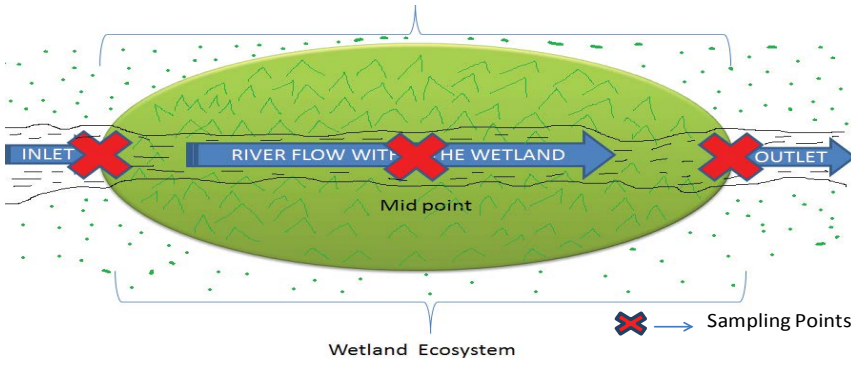

Figure 5: A Sketch Map of a Wetland Showing Sampling of the Respective Wetlands

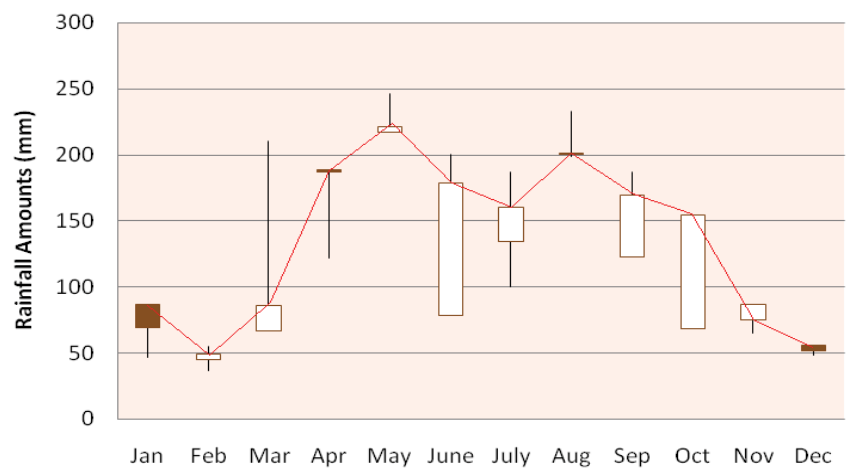

Figure 6: A graph of mean rainfall amounts for Lake Victoria Basic during the years 2009 to 2013

values in all wetlands measured. High precipitation could have led to an increase in sediment load from farms and grazing fields, resuspension of sediments from wetland bottom, high algae growth and phytoplankton's thus increasing turbidity values during rainy season. During the dry season, all wetlands were able to facilitate sedimentation thus lower turbidity values. All values recorded were higher than the recommended turbidity values of below 0.5 NTUs [32-36] this calls for mitigation measures to be put in place to reduce the high sediment loads in such regions like digging terraces, planting of more trees, and formulation of policy.

\section{Statistical analysis of the results at kigwal/kimondi wetland}

\section{ecosystem}

The study observed strongly positive statistically significant correlations between seasonal variation of flow rate and rainfall amounts of the selected wetland ecosystems with $\mathrm{r}_{\text {dry }}=0.9810 ; \mathrm{p}_{\mathrm{dry}}=0.021$ and $\mathrm{r}_{\text {rain }}=0.9971 ; \mathrm{p}_{\text {rain }}=0.001$. The correlation was in agreement with what reported. It is expected as precipitation increases, so does the flow rate of river systems although topography and vegetative cover has a direct effect of the same. A similar relationship was recorded between flow rate and turbidity although statistically insignificant $\left(\mathrm{r}_{\mathrm{dry}}=0.476 ; \mathrm{p}_{\mathrm{dry}}=0.164\right.$; $\left.\mathrm{r}_{\text {rain }}=0.268 ; \mathrm{p}_{\text {rain }}=0.454\right)$. Increase in flow rate therefore corresponded to an increase in turbidity values as water turbulence increases and the wetland bed floor is agitated more. The observation corresponded to what observed. A weak negative statistically insignificant correlation was observed between seasonal comparison of flow rate and $\mathrm{pH}\left(\mathrm{r}_{\mathrm{dry}}=-\right.$ 0.394., $\mathrm{p}_{\text {dry }}=0.259 ; \mathrm{r}_{\text {rain }}=-0.911 ., \mathrm{p}_{\text {rain }}=0.000$ ). A negative correlation was observed between rainfall amounts and $\mathrm{pH}$ values with dry season recording higher $\mathrm{pH}$ values than rain season $\left(\mathrm{r}_{\mathrm{dry}}=-0.2167, \mathrm{p}>0.05\right)$.

A strongly positive statistically significant correlation was observed between $\mathrm{pH}$ and turbidity of Kigwal/Kimondi wetland ecosystem during dry season $\left(r_{d r y}=0.819\right.$., $\left.p_{\text {dry }}=0.004\right)$ although the opposite was true while comparing values of such during rainy season with inverse relationship observed $\left(\mathrm{r}_{\text {rain }}=-0.439 ., \mathrm{p}_{\text {rain }}=0.204\right)$. The relationship between turbidity and dissolved oxygen of Kimondi wetland ecosystem was also reported to be inversely proportional $\left(r_{\text {dry }}=-0.522\right.$., $p_{\text {dry }}=0.122$; $\mathrm{r}_{\text {rain }}=0.357 ., \mathrm{p}_{\text {rain }}=0.311$.

\section{Statistical analysis of the results at nyando wetland ecosystem}

A weak positive statistically insignificant correlation was observed between flow rate and turbidity during dry season $\left(\mathrm{r}_{\text {dry }}=0.328\right.$; $\left.\mathrm{p}_{\mathrm{dry}}=0.355\right)$. An increase in flow rate indicated an increase in turbidity as expected but not statistically significant during dry season of the period under study although a strongly positive statistically significant correlation between flow rate and turbidity of River Nyando wetland ecosystem was noted during rainy season $\left(\mathrm{r}_{\text {rainy }}=0.935 ; \mathrm{p}_{\text {rainy }}=0.000\right)$. This relationship was in agreement with what was observed for the two parameters at Kigwal/Kimondi wetland ecosystem such a correlation during rainy season was due to the increase in flow rate of river water which had in it more sediment load from farms, re-suspension of sediment solids in wetland bed and increase in algae population within River Nyando wetland ecosystem.

A strongly positive statistically significant correlation $\left(\mathrm{r}_{\mathrm{dry}}=0.958\right.$, $\mathrm{p}_{\mathrm{dry}}=0.000$ ) was observed between values of flow rate and $\mathrm{pH}$ of River Nyando wetland ecosystem during dry season as in Table 1. An increase in flow rate related well with an increase in $\mathrm{pH}$ values in River Nyando wetland. A similar strongly positive correlation $\left(\mathrm{r}_{\text {rainy }}=0.850, \mathrm{p}_{\text {rainy }}=0.002\right)$ was reported between the two parameters during the rainy season. The results were not in agreement with the reported observations in Kigwal/Kimondi wetland. This may be due to the complex status of Kimondi wetland in terms of vegetative cover, topography and less anthropogenic activities as compared to River Nyando wetland ecosystem.

\section{Statistical analysis of the results at nzoia wetland ecosystem}

A negative statistically insignificant correlation was observed between flow rate and $\mathrm{pH}$ values within the wetland during dry season $\left(r_{\text {dry }}=-0.156 ; p_{\text {dry }}=0.666\right)$, although, a negative statistically significant correlation between the two parameters was noted during rainy season $\left(\mathrm{r}_{\text {rain }}=-0.775 ; \mathrm{p}_{\text {rain }}=0.008\right)$ thus an increase in flow rate of River Nzoia wetland ecosystem related inversely with $\mathrm{pH}$ values during the period of study. This observation differed with what was observed in Kigwal/ Kimondi and River Nyando wetland ecosystems, majorly due to the fact that River Nzoia traverses many municipal centers, agricultural farms and industries which may have affected the $\mathrm{pH}$ values of the wetland waters.

A strongly positive statistically significant correlation $\left(\mathrm{r}_{\mathrm{dry}}=0.711\right.$, $\left.\mathrm{p}_{\mathrm{dry}}=0.021\right)$ between flow rate and turbidity in samples collected and analyzed during dry season as in Table 1. A similar correlation was observed between the two parameters during the rainy season $\left(\mathrm{r}_{\text {rainy }}=0.854, \mathrm{p}_{\text {rainy }}=0.002\right)$. The results corresponded to the results reported for flow rate and turbidity in Kigwal/Kimondi wetland (Section 4.2.7) and River Nyando wetland ecosystem (Section 4.2.8) since low flow rate contributed to a decrease in turbidity due to high sedimentation of suspended soil particles.

A negative correlation $(\mathrm{r}=-0.602)$ was observed between $\mathrm{pH}$ and turbidity of River Nzoia wetland during the dry season with an increase or decrease in $\mathrm{pH}$ correlating negatively with values of turbidity as in Table 1 . The correlation observed between $\mathrm{pH}$ and turbidity was not 
Citation: Shadrack M, Charles N, Kamau G, Gilbert O, Phanice W, et al (2015) Physical Parameters of Tropical Wetlands in Lake Victoria Basin: A Case Study of Kigwal/Kimondi, Nyando and Nzoia Wetlands. J Environ Anal Toxicol 5: 254. doi:10.4172/2161-0525.1000254

Page 7 of 8

\begin{tabular}{|c|c|c|c|c|c|}
\hline Wetland & Tank & $\begin{array}{l}\text { Recharge Volume during } \\
\text { Rain Season } m^{3}\left(x^{10^{6}}\right)\end{array}$ & $\begin{array}{l}\text { Discharge Volume during } \\
\text { Rain Season in } \mathrm{m}^{3}\left(\times 1^{6}\right)\end{array}$ & $\begin{array}{l}\text { Recharge Volume during } \\
\text { Dry Season } \mathrm{m}^{3}\left(\times 1^{6}\right)\end{array}$ & $\begin{array}{l}\text { Discharge Volume during } \\
\text { Dry Season in } \mathrm{m}^{3}\left(\mathrm{x}^{10^{6}}\right)\end{array}$ \\
\hline \multirow[t]{4}{*}{ Kimondi } & Inlet & $9.30( \pm 4.67)$ & $4.5( \pm 3.81)$ & $5.11( \pm 1.22)$ & $0.91( \pm 0.03)$ \\
\hline & Mid wetland & $4.5( \pm 2.81)$ & $0.93( \pm 0.24)$ & $0.91( \pm 0.13)$ & $0.42( \pm 0.12)$ \\
\hline & Outlet & $0.93( \pm 0.087)$ & $0.45( \pm 0.15)$ & $0.42( \pm 0.12)$ & $0.09( \pm 0.03)$ \\
\hline & Retention Capacity & $8.85( \pm 2.91)$ & & $5.02( \pm 0.09)$ & \\
\hline \multirow[t]{4}{*}{ Nyando } & Inlet & $16.7( \pm 0.21)$ & $10.6( \pm 0.94)$ & $9.81( \pm 0.09)$ & $7.02( \pm 0.12)$ \\
\hline & Mid wetland & $10.6( \pm 0.94)$ & $8.99( \pm 0.37)$ & $7.02( \pm 0.12)$ & $5.66( \pm 0.09)$ \\
\hline & Outlet & $8.99( \pm 0.37)$ & $5.23( \pm 0.11)$ & $5.66( \pm 0.09)$ & $3.54( \pm 0.17)$ \\
\hline & Retention Capacity & $11.47( \pm 0.75)$ & & $6.27( \pm 0.13)$ & \\
\hline \multirow[t]{4}{*}{ Nzoia } & Inlet & $42.1( \pm 0.04)$ & $22.47( \pm 0.18)$ & $19.8( \pm 0.32)$ & $15.02( \pm 4.12)$ \\
\hline & Mid wetland & $22.47( \pm 0.18)$ & $18.32( \pm 1.54)$ & $15.02( \pm 4.12)$ & $11.99( \pm 7.04)$ \\
\hline & Outlet & $18.32( \pm 1.54)$ & $15.86( \pm 5.67)$ & $11.99( \pm 7.04)$ & $8.42( \pm 0.67)$ \\
\hline & Retention Capacity & $26.24( \pm 0.99)$ & & $11.38( \pm 2.48)$ & \\
\hline
\end{tabular}

Table 1: The Mean Water Budget for the Rain season for the Selected Wetland Ecosystems calculated for the periods 2009 to 2013

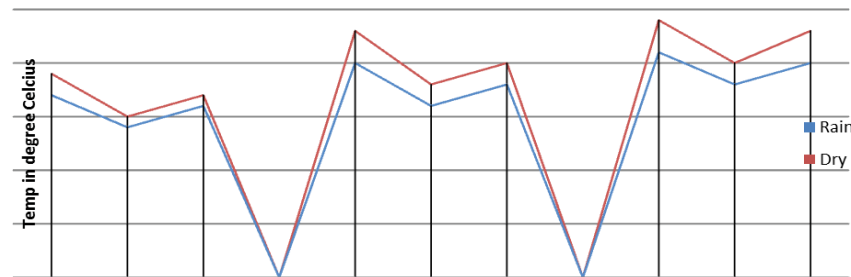

Figure 7: A graph of mean surface water temperatures within the wetland ecosystems

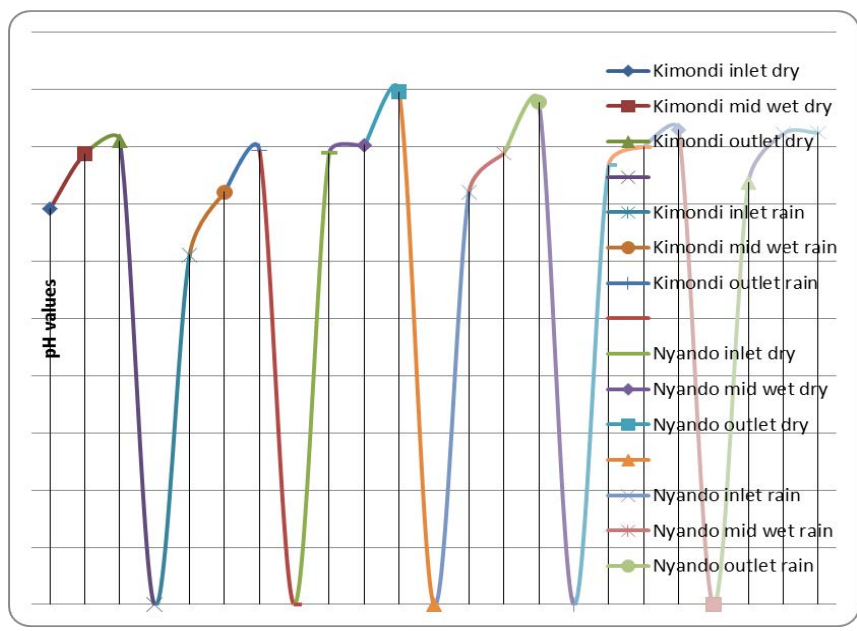

Figure 8: A graph of $\mathrm{pH}$ of selected wetland ecosystems.

statistically significant during the dry season $(\mathrm{p}=0.066)$. A strongly negative correlation $(\mathrm{r}=-0.876)$ existed between $\mathrm{pH}$ and turbidity during rainy season with statistical significance of the correlation reported $(\mathrm{p}=0.001)$. Increase in water sediments from acidic soils may have caused this observation.

\section{Conclusion}

The study found seasonal variations of the measured parameters within the wetland ecosystems with inlet of the wetlands experiencing high water flow rate and turbidity values which decreased as the river system traversed the selected wetland ecosystems. The wetland ecosystems are able to increase water quality of the traversing river system by decreasing suspended solid particles and thus decreasing absorbed pollutants in the solid particles. Such an effect has a direct correlation with levels of pollutants in the ecosystems and thus the study informs that the wetland ecosystems do thereby perform their functions in water purification. There was a direct relationship between rainfall amount and water budgets of the specific wetlands with high precipitation corresponding to high water budgets in the respective tanks of the wetlands. This had a direct influence on the retention of suspended solid materials as turbidity values increased. The increase of $\mathrm{pH}$ values from inlet to the outlet of the wetland is an indication of high vegetative degradation within the wetlands although Nyando and Nzoia wetland ecosystems all had $\mathrm{pH}$ values above 7 . The flow rate of the wetlands was high within the inlets and outlets with mid wetland recording lower values for the seasons under study.

\section{Recommendation}

The study recommends the following as means of improving the wetlands physical parameters and thus improves their functions:

i) Have wetland management and conservation policies implemented by the relevant government authorities which will be aimed at reducing the values of turbidity values at the inlet of the wetlands.

ii) Ensure all stakeholders of wetlands are fully involved in the management and conservation of tropical wetlands as anthopogenic activities do have a direct effect on the wetland $\mathrm{pH}$ values and turbidity.

iii) Implement prudent agricultural policies to protect wetland ecosystems from sedimentation and increase of pollutants from farms within the basin.

iv) Perform research on the pollutant retention ability of tropical wetlands.

\section{Acknowledgement}


Citation: Shadrack M, Charles N, Kamau G, Gilbert O, Phanice W, et al (2015) Physical Parameters of Tropical Wetlands in Lake Victoria Basin: A Case Study of Kigwal/Kimondi, Nyando and Nzoia Wetlands. J Environ Anal Toxicol 5: 254. doi:10.4172/2161-0525.1000254

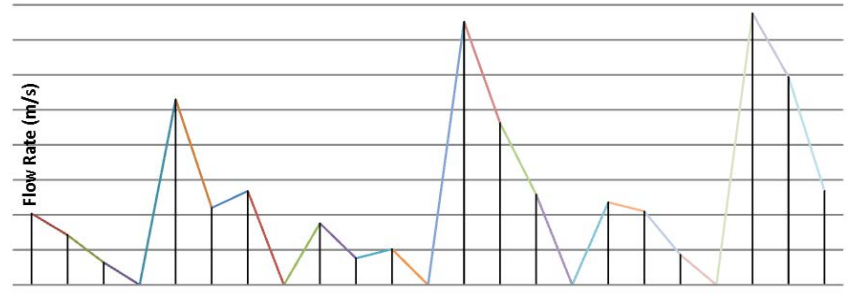

Figure 9: A graph of flow rate of selected wetland ecosystems.

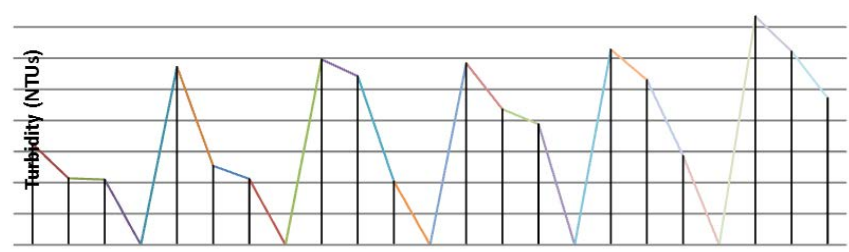

Figure 10: A graph of Turbidity of Selected wetland ecosystems.

I wish to acknowledge all researchers who participated in this research project alongside National Council of Science and Technology who funded the project. My due acknowledgement goes to all lecturers in the Department of Physical Sciences, School of Science and Technology, University of Kabianga.

\section{References}

1. Analytical Procedures and Methods Validation (2000) Chemistry, Manufacturing, and Controls, Federal Register (Notices) 65: 776-777.

2. AOAC (2012) International Method Validation Programs. Peer Verified Programs. Gaithersburg, Maryland, USA.

3. Armwood AJ (2006) The effects of wetland location on the levels of dissolved oxygen. American Geophysical Union, spring meeting.

4. Arnot JA, Gobas FA (2009) A review of bioconcentration factor (BCF) and bioaccumulation factor (BAF) assessments for organic chemicals in aquatic organisms. Environmental Reviews 14: 257-297.

5. Amoako J, Ansa-Asare OD, Karikari AY, Dartey G (2011) Levels of polycyclic aromatic hydrocarbons (PAHs) in the Densu River Basin of Ghana. Environ Monit Assess 174: 471-480.

6. Centers for Disease Control and Prevention (CDC) (2013) Homemade chemical bomb incidents - 15 states, 2003-2011. MMWR Morb Mortal Wkly Rep 62: 498-500.

7. Bäckström M (2002) Sediment transport in grassed swales during simulated runoff events. Water Sci Technol 45: 41-49.

8. Baker LA (2009) In Created and natural wetlands for controlling nonpointsource pollution; Olson RK, Marshall K (Eds) CRC Press: Boca Raton, FL 12-45.

9. Batchelor A, Scott WE, Wood A (2010) In Constructed wetlands in water pollution control; Cooper PF, Findlater BC (Eds) Pergamon Press: Oxford 373-382.

10. Ball S, Bell S, Megillivray D (2000) Environmental Law. In The law and policy relation to the protection of the environment $\left(5^{\text {th }}\right.$ edtn) 726 Blackstone Press.

11. Blankenberg AG, Haarstad K, Braskerud BC (2007) Pesticide retention in an experimental wetland treating non-point source pollution from agriculture runoff. Water Sci Technol 55: 37-44.

12. Blackwell M, Hogan D, Malty E (2012) Agriculture, hydrology and water quality. CAB international, London.

13. Braskerud BC, Haarstad K (2003) Screening the retention of thirteen pesticides in a small constructed wetland. Water Sci Technol 48: 267-274.

14. Conte P, Zena A, Pilidis G, Piccolo A (2001) Increased retention of polycyclic aromatic hydrocarbons in soils induced by soil treatment with humic substances. Environ Pollut 112: 27-31.

15. Brezonik PL, Stadelmann TH (2002) Analysis and predictive models of storm water runoff volumes, loads and pollutant concentration from watersheds in Twin Cities metropolitan area, Minesotoa, USA, Water Res 36: 1743-1757.

16. Brezonik PL, Stadelmann TH (2002) Analysis and predictive models of stormwater runoff volumes, loads, and pollutant concentrations from watersheds in the Twin Cities metropolitan area, Minnesota, USA. Water Res 36: 1743-1757

17. Carleton JN, Grizzard TJ, Godrej AN, Post HE (2001) Factors affecting the performance of stormwater treatment wetlands. Water Res 35: 1552-1562.

18. Chanson H (2004) The Hydraulics of Open Channel Flow, ButterworthHeinemann, Oxford, UK (2nd edn) 630.

19. Clescerl, Leonore S, Greenberg, Arnold E, Eaton, Andrew D (2007) Standard Methods for the Examination of Water and Wastewater (20th Ed) American Public Health Association, Washington, DC

20. Haarstad K, Braskerud BC (2003) Pollutants in soils in small contructed wetland. Water Sci Technol 40: 54-57

21. Haarstad K, Braskerud BC (2005) Pesticide retention in the watershed and in a small constructed wetland treating diffuse pollution. Water Sci Technol 51 $143-150$.

22. Hedman CW, Davidson B, Naddy B (2006) In-stream large woody debris loading and riparian forest serai stage associations in the southern Appalachian Mountains. Can J For Res 26: 1218-1227.

23. Horner H, Brock TC, VanWijngaarden V (2004) Ecological Risk of Pesticides in Freshwater Ecosystems. Part 2. Water Sci Technol 20: 43-76

24. Jesús MA, López-Muñoz MJ, José A, Arcadio S (2008) Temperature, pH and concentration effects on retention and transport of organic pollutants across thin-film composite nanofiltration membranes. Desalination 221: 253-258.

25. Kadlec RH, Knight RL (2006) Treatment Wetlands. CRC Lewis: Boca Raton, FL.

26. Kohler EA, Poole ZJ, Reicher VL, Turco RF (2004) Nutrient, metal, and pesticide removal during storm and nonstorm events by a constructed wetland on an urban golf course. Ecological Engineering 23: 285-298.

27. Laskowski DA (2002) Physical and chemical properties of pyrethroids. Rev Environ Contam Toxicol 174: 49-170.

28. Lewis MA, Mayer FL, Powell RL, Nelson MK, Klaine SI, et al. (2009) Ecotoxicology and risk assessment for wetlands; Society of Environmental Toxicology and Chemistry (SETAC): Pensacola, FL.

29. Mackay D, Shiu WY, Ma KC, Lee SC (2006) Handbook of Physical-Chemical Properties and Environmental Fate for Organic Chemicals. Volume IV. Nitrogen and Sulfur Containing Compounds and Pesticides. New York: CRC Press.

30. Michael Hogan C (2010) Water pollution. Encyclopedia of Earth. Topic ed. Mark McGinley (ed) C Cleveland National Council on Science and the Environment, Washington, DC.

31. Michael H, Bi-Xian M, Guo-Ying S (2007) Chlorinated and polycyclic aromatic hydrocarbons in riverine and estuarine sediments from Pearl River Delta China. Bulletin of Environmental Contamination and Toxicology 66: 200-210

32. Ministry of Environment and Natural Resources (2010) Kenyan Wetlands and their Protection.

33. Mitsch W, Gosselink J (2003) Wetlands. 2nd Ed. Van Nostrand Rheinhold, New York.

34. Pontolillo J, Eganhouse RP (2010) The search for reliable aqueous solubility (SW) and octanol-water partition coefficient (KOW) data for hydrophobic organic compounds--DDT and DDE as a case study: U.S. Geological Survey Water-Resources Investigations 01-4201: 51.

35. Ralfschul Z, Suek CP (2001) Effectiveness of a Constructed Wetland for Retention of Nonpoint-Source Pesticide Pollution in the Lourens River Catchment, South Africa. Environ Sci Technol 35: 422-426.

36. Shukla W, Naggy V, Betty D (2006) Waste water retention on wetlands in Australia. Journal of Environmental Quality 42:12-22. 